\title{
Genetic variation in the adiponectin receptor 2 (ADIPOR2) gene is associated with coronary artery disease and increased ADIPOR2 expression in peripheral monocytes
}

losif Halvatsiotis ${ }^{1,2}$, Panayoula C Tsiotra ${ }^{1 *}$, Ignatios Ikonomidis ${ }^{3}$, Anastasios Kollias ${ }^{1,2}$, Panagiota Mitrou ${ }^{1}$, Eirini Maratou', Eleni Boutati ${ }^{2}$, John Lekakis ${ }^{3}$, George Dimitriadis², Theofanis Economopoulos²,

Dimitrios T Kremastinos ${ }^{3}$, Sotirios A Raptis ${ }^{1,2}$

\begin{abstract}
Background: Adiponectin is an adipose tissue secreted protein known for its insulin sensitising and antiatherogenic actions. To this date two adiponectin receptors have been discovered, adiponectin receptor 1 (ADIPOR1) and adiponectin receptor 2 (ADIPOR2). The aim of this study was to investigate the association of ADIPOR2 gene variations with coronary artery disease (CAD).
\end{abstract}

Methods: Eight common single nucleotide polymorphisms (SNPs) spanning the entire ADIPOR2 locus were chosen to perform association studies with anthropometric and metabolic parameters in a Greek population. They were classified as either CAD (stenosis $>50 \%$ in at least one main vessel) or non-CAD individuals in accordance with coronary angiography data.

Genotyping was performed using a microsphere-based suspension array and the Allele Specific Primer Extension (ASPE) method. Expression of ADIPOR2 protein and mRNA in circulating $\mathrm{CD}_{14}{ }^{+}$monocytes were determined using flow cytometry and real time Polymerase Chain Reaction assays respectively.

Results: There was a significant difference in the distribution of genotypes of polymorphism rs 767870 of ADIPOR2 between CAD and non-CAD individuals $(p=0.017)$. Furthermore, heterozygotes of the rs767870 polymorphism had significantly lower Flow Mediated Dilatation (FMD) values, higher values of Intima-Media Thickness (IMT) and increased ADIPOR2 protein levels in peripheral monocytes, compared to homozygotes of the minor allele after adjustment for age, sex, waist to hip ratio and HOMA.

Conclusions: Our findings suggest that variants of ADIPOR2 could be a determinant for atherosclerosis independent of insulin resistance status, possibly by affecting ADIPOR2 protein levels.

\section{Background}

Adiponectin is a protein secreted from adipocytes released in the circulation of human healthy subjects at relatively high levels [1-4]. Plasma adiponectin levels have been reported as decreased in states of obesity, type 2 diabetes and coronary artery disease [5-8]. Adiponectin exerts its insulin-sensitising effects in the liver by suppressing gluconeogenesis and in the skeletal muscle

\footnotetext{
*Correspondence: ytsiotra@hndc.gr

${ }^{1}$ Hellenic National Centre for the Research, Prevention and Treatment of Diabetes Mellitus and its Complications (HNDC), Athens, Greece
}

by enhancing fatty acid oxidation [9]. Furthermore, adiponectin exhibits anti-inflammatory and atheroprotective actions in various tissues by suppressing the expression of vascular adhesion molecules and scavenger receptors, reducing the expression of the inflammatory cytokine TNF- $\alpha$, raising NO production and suppressing the proliferation and migration of smooth muscle cells [10-14].

To this date, two receptors have been identified that mediate adiponectin's actions in fatty-acid oxidation and glucose uptake, namely ADIPOR1 and ADIPOR2 [15]. 
Both receptors are almost ubiquitously expressed in most tissues, albeit at different levels, and studies aimed at their mRNA and protein expression levels in various insulin resistant states have produced inconclusive results [16-18]. It has been reported that the expression of these receptors is either induced or reduced in adipose and muscle tissues from obese and insulin resistant subjects $[19,20]$. Furthermore, it was recently shown that monocytes from overweight and obese individuals with type 2 diabetes compared to normal-weight controls have an impaired expression of adiponectin receptors [21].

ADIPOR2 is a cell-surface receptor abundantly expressed in skeletal muscle and liver, serving as a receptor for both globular and full-length adiponectin. Its protein expression has been demonstrated to be either up-regulated in adipose tissue from insulin resistant women with polycystic ovarian syndrome, or downregulated in monocytes from overweight/obese patients with type 2 diabetes $[19,21]$. Similarly, its mRNA expression in skeletal muscle and adipose tissues from obese, insulin resistant or type 2 diabetic patients follows the same inconclusive results $[17,18]$. The ADIPOR2 gene is located on chromosome 12p13.33, consisting of eight exons. Single nucleotide polymorphisms (SNPs) of the ADIPOR2 have been associated with either insulin resistance or hepatic fat accumulation in various populations [22-29], albeit not in all studies [30-33]. Nevertheless, the role of genetic variants of $A D I P O R 2$ in coronary artery disease has not been studied yet.

In this study, we investigated the association between eight common single nucleotide polymorphisms of the ADIPOR2 gene with the presence of coronary artery disease and its protein expression from human peripheral monocytes from the same individuals.

\section{Methods}

\section{Subjects}

Our study analysis consisted of 68 patients from the Greek population with cardiovascular risk factors, who were screened for the existence of chronic stable CAD. All individuals underwent elective coronary angiography. Case subjects $(n=40)$ were patients who had angiographic evidence of stenosis $>50 \%$ in at least one major coronary artery (CAD). Control subjects $(n=28)$ were people without coronary stenosis at angiography (nonCAD). Subjects with acute myocardial infarction, systemic inflammatory diseases, malignancies, renal failure (creatinin $>1.5 \mathrm{mg} / \mathrm{dl}$ ), heart failure and severe obesity with body mass index $(\mathrm{BMI})>35$ were excluded from our study.

All patients gave their written informed consent and the study protocol was approved by the Scientific and Ethics Committee of Attikon University General
Hospital. All patients were of a stable weight and had been on a normal isocaloric diet with normal physical activity during the previous four months. None of the patients were taking thiazolidinedione medication. Waist and hip circumferences were measured and the waist to hip ratio (WHR) was calculated. BMI was calculated as the ratio of weight $(\mathrm{Kg})$ to height $\left(\mathrm{m}^{2}\right)$. All patients were subjected to Intima-Media Thickness (IMT) assessment in common carotids and in carotid bulbs as an index of atherosclerosis, using B-mode ultrasound imaging (Vivid 7 General Electric Horten, Norway), as previously described [34] and Flow Mediated Dilatation (FMD) assessment of the brachial artery as an index of endothelial dysfunction [35].

The coronary angiography was followed by a 2-hour oral glucose tolerance test (OGTT) two weeks later. Insulin resistance status in the fasting state was calculated by the homeostasis model assessment index (HOMA) [36], whilst post-glucose insulin sensitivity was calculated by the Matsuda index [37]. Fasting blood was drawn at the beginning of the OGTT and plasma was kept at $-80^{\circ} \mathrm{C}$ for measurement of adiponectin levels. Fasting triglycerides, as well as total and high-density lipoprotein (HDL) cholesterol were determined by an ILAB Analyser (Instrumentation Laboratory SpA, Italy). Plasma glucose levels at fasting and during the OGTT were analysed on a Falcor 300 chemical analyser (Menarini diagnostics, Italy) and their corresponding insulin levels were measured by IRMA (INSI-CTK, Dia Sorin, Italy).

\section{Genomic DNA isolation}

Fasted blood was collected from all individuals and genomic DNA was extracted from the buffy coat according to the manufacturer's instructions (Flexigene DNA Kit, Qiagen, Chatsworth, CA, USA). The quality and the integrity of the DNA samples was determined by standard ethidium-bromide agarose gels and quantification was performed spectrophotometrically (UV/VIS Spectrometer Lambda Bio10, Perkin Elmer, USA). The following common single nucleotide polymorphisms were examined lying either in the promoter [rs10773980 $\mathrm{C} / \mathrm{T}$ and rs1029629 $\mathrm{C} / \mathrm{T}]$, the intron 5 [rs767870 A/G], the exon 6 [rs16928751 G/A], the exon 7 [rs9805042 $\mathrm{C} / \mathrm{T}$ and I290I $\mathrm{C} / \mathrm{A}]$ and the exon 8 [rs12342 C/T and rs1044771 C/T] of ADIPOR2 (Fig. 1).

\section{Genotyping of ADIPOR2 polymorphisms using the Allele Specific Primer Extension (ASPE)}

The Allele Specific Primer Extension assay and xMAP technology were used to genotype our samples. This technique is a solution-based sequence-specific enzymatic reaction that determines the target SNPs. It involves the incorporation of a specific capture 


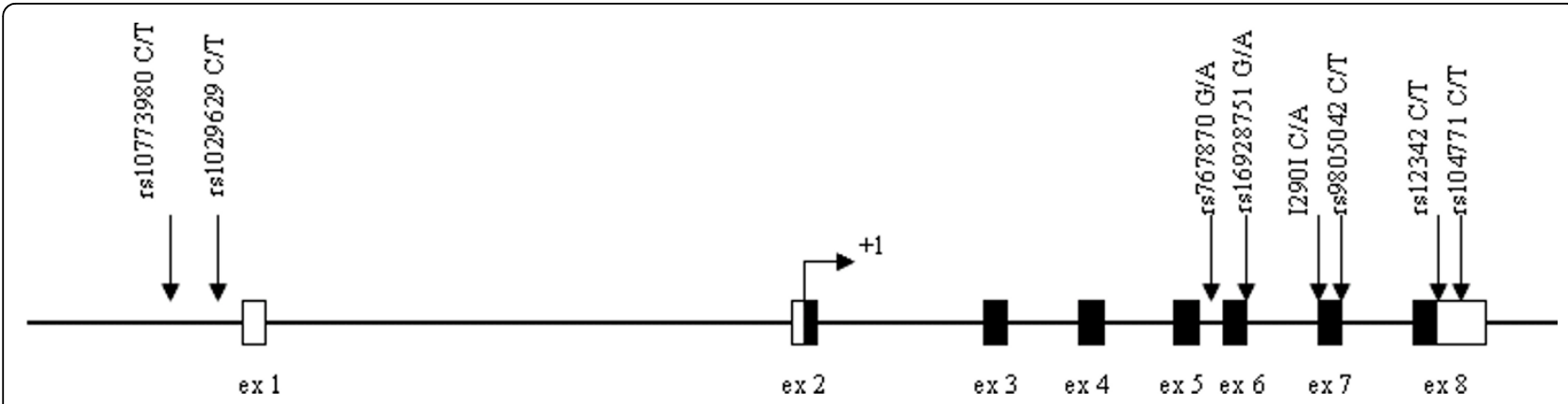

Figure 1 Schematic representation of the ADIPOR2 gene. The polymorphisms studied are represented by vertical arrows. Empty boxes denote exons and black boxes denote sequences translated into protein. +1 represents the ATG translation start site.

sequence, named Allele Specific Primer Extension (ASPE) that carries the major or the minor nucleotide of the SNP at its 3' -end $[38,39]$. Therefore, two ASPE primers are needed for every SNP in order to resolve each possible allele pair. ASPE primers also carry a tagsequence which hybridises to a complementary sequence called anti-tag, in the surface of the polystyrene microspheres (xMAP microspheres), which are internally dyed with fluorophores.

Various PCR products encompassing the SNPs of interest, ranging in size from 353 to $1180 \mathrm{bp}$, were generated through standard PCR reactions from human genomic DNA, using Platinum Taq Polymerase (Invitrogen, Carlsbad, CA, USA) in a GeneAmp 9600 thermocycler (Perkin Elmer Inc, Massachusetts, USA). An aliquot from the PCR reactions was run on 1.5\% agarose gels and visualised with ethidium bromide staining. Product lengths were estimated using a standard molecular weight marker (ФX174-HaeIII digest, NEB, UK) (Fig 2A and $2 \mathrm{~B}$ ) and subsequently the PCR products were treated with exo-SAP mix (2:1) (Exonuclease I:Shrimp Alkaline Phosphatase, USB Europe $\mathrm{GmbH}$, Germany) at $37^{\circ}$ $\mathrm{C}$ for 30 minutes in order to remove unconsumed dNTPs and primers remaining in the mixture, followed by inactivation at $80^{\circ} \mathrm{C}$ for 15 minutes. Consequently the treated PCR products were combined with ASPE primers and extension took place with the use of biotin14-dCTP and Platinum Tsp DNA Polymerase (Invitrogen, Carlsbad, CA, USA). Extension occurs only if the 3' nucleotide of the ASPE primer is complementary to the template DNA. The conditions for the ASPE reaction were as follows: denaturation at $96^{\circ} \mathrm{C}$ for 2 minutes, amplification for 40 cycles at $95^{\circ} \mathrm{C}$ for 30 seconds, $54^{\circ} \mathrm{C}$ for 30 seconds and $74^{\circ} \mathrm{C}$ for 60 seconds, followed by one cycle at $4^{\circ} \mathrm{C}$. The subsequent hybridisation of the anti-tag microsphere to the biotinilated ASPE-tag PCR product took place at $37^{\circ} \mathrm{C}$ for 60 minutes, after a short denaturation cycle at $95^{\circ} \mathrm{C}$ for 90 seconds.

Finally, a fluorescent-labelled reporter molecule (Streptavidin-R-phycoerythrin, $1 \mathrm{mg} / \mathrm{ml}$, Molecular
Probes, Invitrogen, Carlsbad, CA, USA) binds to the biotinilated hybrid ASPE microsphere product. This coupling of the reporter molecule quantifies the biomolecular interaction that occurs at the microsphere surface. The reaction can finally be analysed on a Luminex 200 instrument (Luminex Corp, TX, USA). Precision fluidics aligns the microspheres in single file and passes them through the lasers, one at a time. One laser excites the reporter molecule bound to the microsphere surface and the second laser excites the microsphere fluorophores. Reactions are measured with fluorescent intensity and reported in real time. The fluorescent signals generated for each microsphere bead population were used to assess the genotype in each sample. The median fluorescent intensities (MFI) were used to calculate allelic rations for each allele as follows:

$$
\text { Allelic Ratio }=\frac{\text { MFI allele } a 1}{(\text { MFI allele } a 1+\text { MFI allele } a 2)}
$$

To be homozygous for a particular allele, the allelic ratio must be at least 0.75 . For heterozygous samples each allele must have a ratio between 0.25 and 0.75 . An allele with a ratio of 0.25 or less is considered negative i. e. not present. Representative samples results are shown in figure 3A.

Determination of ADIPOR2 mRNA and protein expression Peripheral monocytes were isolated from mononuclear cells using a Magnetic Cell-Sorting technique and the CD14 Human MicroBeads (Miltenyi Biotec, Gladbach, Germany). The purity of the magnetically isolated $\mathrm{CD}_{14}{ }^{+}$monocytes was determined after staining the cells with a CD14 PE-CD45 FITC antibody (BD Biosciences, San Jose, CA, USA).

Total RNA was extracted from $\mathrm{CD} 14^{+}$monocytes using the Tripure Isolation Reagent (Roche Diagnostics $\mathrm{GmbH}$, Mannheim, Germany). Reverse transcription of $1 \mu \mathrm{g}$ of total RNA was performed in all samples with the Transcriptor First Strand cDNA Synthesis Kit using 

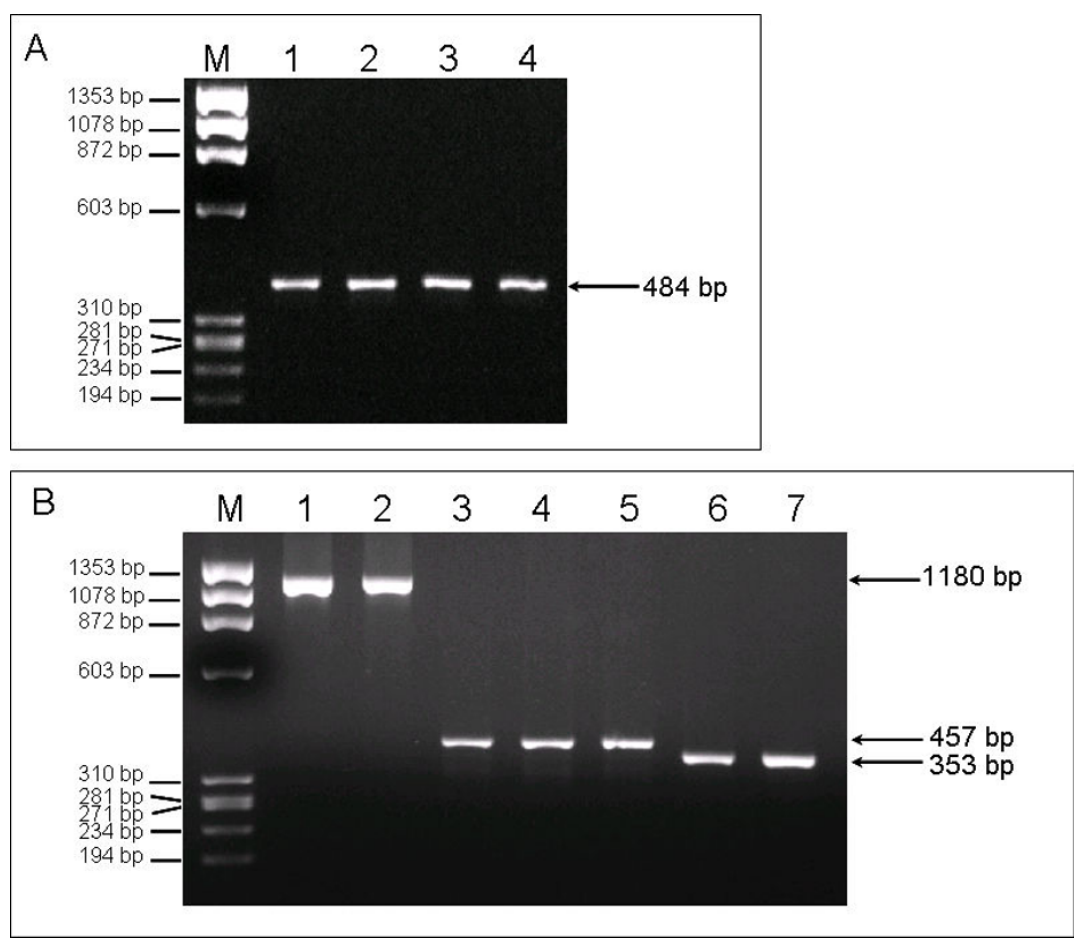

Figure 2 Representative PCR reactions showing the PCR specific bands for all polymorphisms studied of the ADIPOR2 (A). Detection of the PCR specific bands for polymorphism rs767870, lanes 2 and 3 show the PCR specific bands amplified from human genomic DNA from two CAD individuals, while lanes 4 and 5 show the PCR bands amplified from human genomic DNA from two non-CAD individuals. (B) Detection of the PCR specific bands for polymorphisms: rs10773980 (lane 1), rs1029629 (lane 2), rs16928751 (lane 3), 1290l (lane 4), rs9805042 (lane 5), rs12342 (lane 6) and rs1044771 (lane 7). Arrows show the base pair size of the various PCR products. M: ФX174-Haelll digest

random hexamer primers, according to the manufacturer's instructions (Roche Diagnostics GmbH, Mannheim, Germany).

A quantitative real-time PCR using fluorescent-labelled hybridisation probes was developed for detecting relative ADIPOR 2 mRNA levels, in human CD $14^{+}$monocytes, using the calibrator-normalised standard curve and the LightCycler Relative Quantification 1.0.1 Software, in a spectrofluorometric thermal cycler (LightCycler, ROCHE, Manheim, Germany), as previously described [40]. The human housekeeping gene of $\beta$-actin was used as standard for normalisation. Hybridisation specific primers and fluorescent-labelled hybridisation specific probes for the genes were designed and manufactured by the TIMMOLBIOL (Berlin, Germany). Hybridisation primers and probes for the target and reference genes were as follows:

\begin{tabular}{|l|l|l|}
\hline & \multicolumn{1}{|c|}{ 5'-sense primer-3' $^{\prime}$} & \multicolumn{1}{c|}{$5^{\prime}$-a-sense primer-3' } \\
\hline $\begin{array}{l}\text { AdipoR2 } \\
\beta \text {-actin }\end{array}$ & $\begin{array}{l}\text { TGACATCTGGTTTCACTCTCATCAG } \\
\text { CTTCTACAATGAGCTGCGTGTG }\end{array}$ & $\begin{array}{l}\text { GTCATAGTCCCTGGAGACTGGT } \\
\text { GTGAGGATCTTCATGAGGTAGTCAGTC }\end{array}$ \\
\hline
\end{tabular}

\begin{tabular}{|l|l|l|}
\hline & \multicolumn{1}{|c|}{ 5'-FL probe-3' $^{\prime}$} & \multicolumn{1}{|c|}{ 5'-LC Red640 probe-3' $^{\prime}$} \\
\hline $\begin{array}{l}\text { AdipoR2 } \\
\beta \text {-actin }\end{array}$ & $\begin{array}{l}\text { CCTGGAGGTTTGAGACACCATGGAAG } \\
\text { GGTATGCCCTCCCCCATGCC }\end{array}$ & $\begin{array}{l}\text { GACAAAAGCTCCAGCAACCACAAAGATA } \\
\text { TCCTGCGTCTGGACCTGGCTG }\end{array}$ \\
\hline
\end{tabular}

Primers were chosen to lie between exons whenever possible and the analysis was performed with the programme OLIGO 6.0 (Molecular Biology Insights, Cascade, USA).

For quantifying the relative expression levels of $A D I$ POR2 mRNA in the various samples, we ran the target (AdipoR2) and the reference ( $\beta$-actin) gene of each sample along with the calibrator cDNA, using the Second Derivative Maximum Method with the Arithmetic baseline adjustment for the determination of the various crossing points (Fig 3B). Samples were run in duplicates or triplicates and results are expressed in arbitrary units.

Surface adiponectin receptor ADIPOR2 was determined after staining the isolated cells ('buffy'coat) with a suitable antibody (Alpha Diagnostic International, San Antonio, USA). Since the antibody was not fluorochrome conjugated, it was labelled with the Zenon ${ }^{\mathrm{mm}}$ Alexa Fluor ${ }^{\ominus} 488$ Rabbit IgG labelling kit (Invitrogen, Carlsbad, CA, USA). Cells were incubated for $30 \mathrm{~min}$ utes with Alexa Fluor ${ }^{\oplus} 488$-conjugated immunoglobulin in a ratio $1 \times 10^{6}$ cells $\mu \mathrm{g}^{-1}$ of immunoglobulin under mild constant shaking. The monocyte fraction was simultaneously stained with anti-CD14-PE monoclonal antibody (BD Biosciences, San Jose, CA, USA). The 


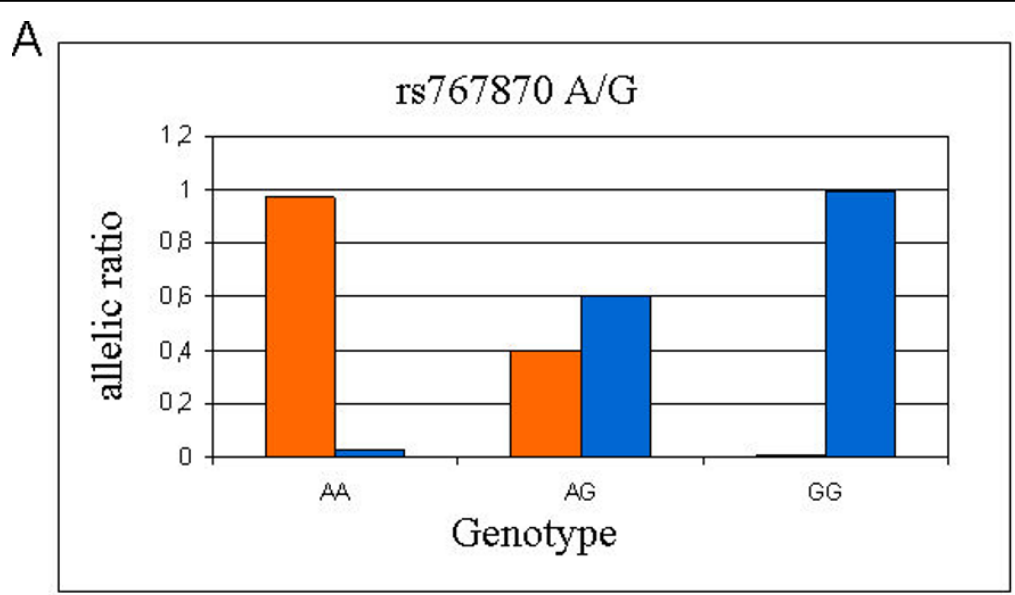

$\mathrm{B}$

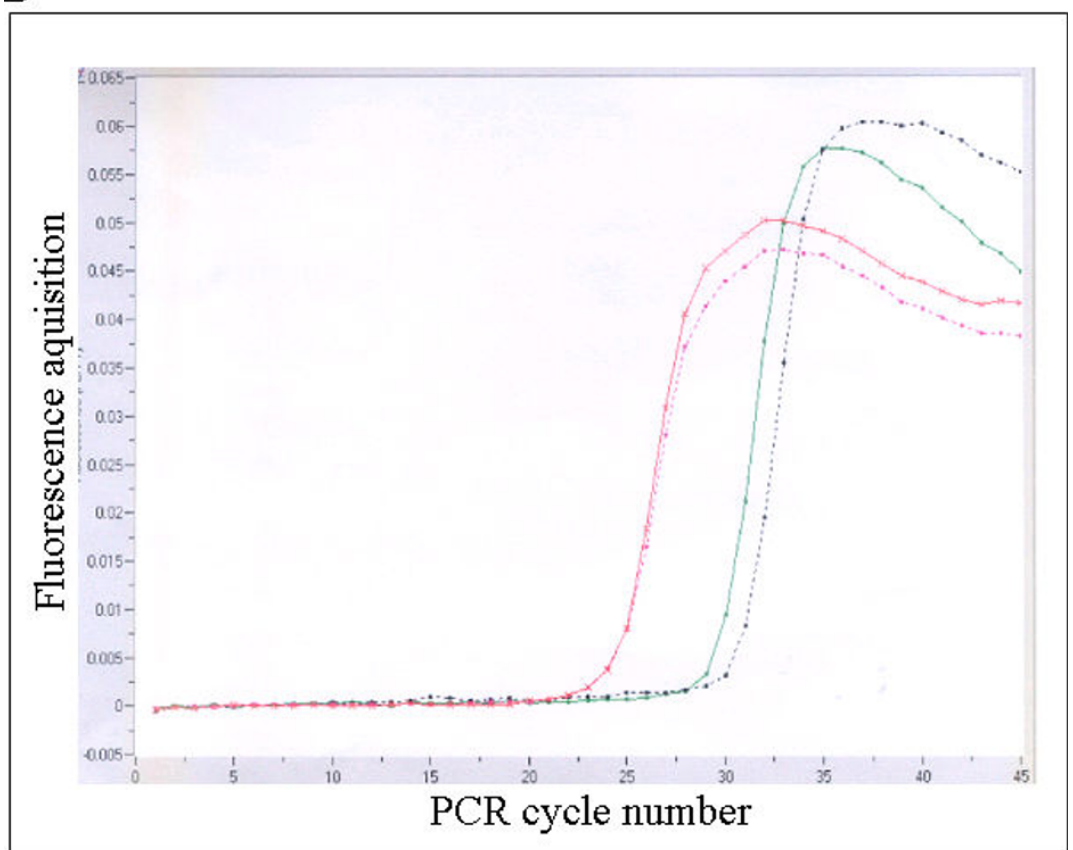

Figure 3 Diagrammatic representation of: (A) the genotyping results for rs767870 polymorphism of ADIPOR2 using the Allele Specific Primer Extension assay and the XMAP technology and (B) the detection of the relative ADIPOR2 mRNA levels using the real-time PCR assay. A. Bars represent the two alleles of the rs767870 polymorphism (G allele: blue bars, A allele: orange bars). The results show three different individuals: on the left, an individual homozygote for the A allele (AA genotype), in the centre, a heterozygote carrying both alleles (AG genotype) and on the right side, a homozygote for the G allele (GG genotype). B. A quantification analysis screen from a typical real-time PCR run, showing the fluorescence acquisition for the ADIPOR2 (green and black curves) and the $\beta$-actin (red and pink curves) mRNA levels on the $y$ axis and the number of cycles on the $x$ axis. Results are shown for two different individuals, a CAD (green and red curves) and a non-CAD individual (black and pink curves).

specificity of the antibody used was evaluated by staining cells with isotype control suitable for each antisera and the blockage of Fc-receptors prior to staining.

Two-colour flow cytometric analysis was performed on a BD FACSCalibur 4 colour flow cytometer (BD Biosciences) equipped with two air-cooled lasers: a 15 mW Argon laser (488 nm) and a Red Diode laser (632 $\mathrm{nm})$. Data acquisition and analysis were performed using the BD CELL Quest Pro software (BD Biosciences). Results are expressed in mean fluorescence intensity arbitrary units (MFI AU).

\section{Adiponectin plasma levels}

Circulating levels of adiponectin were measured in the plasma of all subjects, using a high sensitivity multiplex assay (xMAP technology) and fluorescent-labelled 
microsphere beads (HCVD1-67AK Lincoplex kit, Millipore Corp., MA, USA), in a LUMINEX 200 instrument (Luminex Corp, TX, USA). Sensitivity of the assay was $56.0 \mathrm{pg} / \mathrm{ml}$, intra-assay and inter-assay coefficients of variation were $9.2 \%$ and $15.9 \%$, respectively. All samples were diluted 1:100 and measured in duplicate. Samples that could not be detected were measured again using a higher dilution.

\section{Statistical analysis}

Statistical analysis was performed using the SPSS version 14.0 software (Chicago IL, USA). Deviation of SNPs from the Hardy-Weinberg equilibrium was performed using the chi-square test and the Hardy-Weinberg equilibrium calculator [41]. If genotype frequencies for a particular SNP differ from those expected under equilibrium, the Hardy-Weinberg principle is being violated and is therefore not safe to try to associate this SNP with coronary artery disease. Distribution of alleles was compared using the $\chi^{2}$ and the level of significance adopted was $\mathrm{p}<0.05$. The whole population odds ratio associated with genotypes was calculated by binary logistic regression analysis. Normal distribution was tested with the Kolmogorov-Smirnov test and logistic transformations of variances to achieve normal distribution were used when needed. The differences in various variables between genotypes were evaluated with the univariate ANOVA, adjusted for age, sex, BMI and HOMA. Kruskal-Wallis test was also used when homogeneity of variances were not met. Non-parametric Mann-Whitney and 2-independent samples t-tests were used accordingly for analysis. Data are expressed as means \pm SEM.

\section{Results}

\section{General characteristics of the subjects}

The clinical and metabolic characteristics of the population studied (CAD and non-CAD) are shown in table 1. There were no significant differences between the two groups regarding age, weight, BMI, fasting and two-hour glucose and insulin levels, insulin resistance indices (HOMA and Matsuda), lipid levels (total cholesterol, LDL, HDL), systolic and diastolic blood pressure, endothelial dysfunction (FMD) and the circulating adiponectin (Table 1). However, CAD patients had higher WHR and IMT values compared to control subjects (Table 1). Furthermore, CAD subjects had higher ADIPOR2 mRNA levels, while they did not differ in

Table 1 Anthropometric and metabolic characteristics of the people studied

\begin{tabular}{|c|c|c|c|}
\hline & NonCAD $(n=28)$ & CAD $(n=40)$ & $p$ \\
\hline \multicolumn{4}{|l|}{ Anthropometric characteristics } \\
\hline Age (years) & $56.61 \pm 1.47$ & $59.80 \pm 1.34$ & NS \\
\hline Body weight (kg) & $80.28 \pm 2.09$ & $83.69 \pm 1.51$ & NS \\
\hline $\mathrm{BMI}\left(\mathrm{Kg} / \mathrm{m}^{2}\right)$ & $28.12 \pm 0.51$ & $28.53 \pm 0.49$ & NS \\
\hline WHR & $0.93 \pm 0.01$ & $0.99 \pm 0.01$ & 0.001 \\
\hline \multicolumn{4}{|l|}{ Metabolic characteristics \& Indices } \\
\hline Fasting plasma glucose (mg/dl) & $106.76 \pm 6.19$ & $113.29 \pm 4.5$ & NS \\
\hline Two-hour plasma glucose (mg/dl) & $162.81 \pm 15.30$ & $199.35 \pm 12.79$ & NS \\
\hline Fasting plasma insulin ( $\mu \mathrm{U} / \mathrm{ml})$ & $14.39 \pm 1.84$ & $13.79 \pm 1.15$ & NS \\
\hline Two-hour plasma insulin ( $\mu \mathrm{U} / \mathrm{ml})$ & $100.09 \pm 12.74$ & $135.41 \pm 22.53$ & NS \\
\hline HOMA index & $3.80 \pm 0.58$ & $4.68 \pm 0.69$ & NS \\
\hline Matsuda index & $2.84 \pm 0.24$ & $2.68 \pm 0.25$ & NS \\
\hline Total cholesterol (mg/dl) & $193.26 \pm 8.55$ & $183.32 \pm 5.85$ & NS \\
\hline LDL (mg/dl) & $128.00 \pm 8.68$ & $122.71 \pm 4.88$ & NS \\
\hline $\mathrm{HDL}(\mathrm{mg} / \mathrm{dl})$ & $49.29 \pm 2.62$ & $45.97 \pm 1.97$ & NS \\
\hline Trigycerides (mg/dl) & $114.46 \pm 10.04$ & $133.39 \pm 10.95$ & NS \\
\hline Systolic blood pressure (mm Hg) & $122.32 \pm 2.94$ & $128.06 \pm 2.57$ & NS \\
\hline Diastolic blood pressure $(\mathrm{mm} \mathrm{Hg})$ & $76.25 \pm 1.76$ & $78.89 \pm 1.34$ & NS \\
\hline IMT(mm) & $0.83 \pm 0.05$ & $1.09 \pm 0.05$ & 0.001 \\
\hline IMT bulb (mm) & $1.13 \pm 0.15$ & $1.45 \pm 0.08$ & NS \\
\hline FMD (\%) & $8.59 \pm 1.28$ & $7.01 \pm 0.81$ & NS \\
\hline Adiponectin $(\mu \mathrm{g} / \mathrm{ml})$ & $13.01 \pm 1.09$ & $13.18 \pm 1.30$ & NS \\
\hline ADIPOR2 mRNA (AU) & $0.81 \pm 0.06$ & $1.2 \pm 0.16$ & 0.035 \\
\hline ADIPOR2 protein (MFI) & $82.97 \pm 9.83$ & $65.60 \pm 4.68$ & NS \\
\hline
\end{tabular}

Data are given as means \pm SEM. BMI: Body Mass Index, LDL: Low Density Lipoprotein, HDL: High Density Lipoprotein, IMT: Intima Media Thickness; FMD: Flow Mediated Dilatation. 
ADIPOR2 protein expression, from peripheral CD14 ${ }^{+}$monocytes, compared to controls.

\section{Allele frequencies of ADIPOR2 polymorphisms}

The allele frequencies of the investigated polymorphisms of the ADIPOR2 are shown in table 2. Only rs767870 and rs1044771 polymorphisms were found to be in Hardy-Weinberg equilibrium, $\left(\mathrm{p}<0.05, \chi^{2}<3.83\right)$. Thus we excluded from further analysis, any polymorphism that deviated from Hardy-Weinberg equilibrium.

Association of rs767870 SNP with coronary artery disease We subsequently investigated the distribution of genotypes for the rs767870 and rs1044771 polymorphisms between the two populations and their possible association with coronary artery disease (Table 3 ). There was a significant difference in the distribution of alleles of rs767870 polymorphism of ADIPOR2 between CAD and non-CAD individuals ( $\mathrm{p}=0.017$ ).

No significant difference was found in the distribution of alleles for the rs1044771 polymorphism of ADIPOR2 between the two groups (Table 3 ).

Using binary logistic regression analysis, the risk for CAD for AG heterozygotes of the rs767870 polymorphism was $50 \%$ higher compared to AA homozygotes of the same polymorphism, although not to a significant degree $(\mathrm{OR}=1.543$ and 95\% CI: 0.4655.120) (Table 3). Furthermore, the marker rs767870 of

Table 2 Allele frequencies of ADIPOR2 gene polymorphisms in the Greek population studied

\begin{tabular}{ccc}
\hline Polymorphism & Major/minor allele & allele frequencies \\
\hline rs10773980 C/T & $\mathrm{C} / \mathrm{T}$ & $\mathrm{C}: 0.507, \mathrm{~T}: 0.492$ \\
\hline $\mathrm{rs} 1029629 \mathrm{C} / \mathrm{T}$ & $\mathrm{C} / \mathrm{T}$ & $\mathrm{C}: 0.662, \mathrm{~T}: 0.338$ \\
\hline $\mathrm{rs} 767870 \mathrm{~A} / \mathrm{G}$ & $\mathrm{A} / \mathrm{G}$ & $\mathrm{A}: 0.801, \mathrm{G}: 0.199$ \\
\hline $\mathrm{r} 16928751 \mathrm{G} / \mathrm{A}$ & $\mathrm{G} / \mathrm{A}$ & $\mathrm{G}: 0.853, \mathrm{~A}: 0.147$ \\
\hline $\mathrm{I} 290 \mathrm{C} / \mathrm{A}$ & $\mathrm{C} / \mathrm{A}$ & $\mathrm{C}: 0.889, \mathrm{~A}: 0.111$ \\
\hline $\mathrm{rs} 9805042 \mathrm{C} / \mathrm{T}$ & $\mathrm{C} / \mathrm{T}$ & $\mathrm{C}: 0.632, \mathrm{~T}: 0.368$ \\
\hline $\mathrm{rs} 12342 \mathrm{C} / \mathrm{T}$ & $\mathrm{C} / \mathrm{T}$ & $\mathrm{C}: 0.507, \mathrm{~T}: 0.493$ \\
\hline $\mathrm{rs} 1044771 \mathrm{C} / \mathrm{T}$ & $\mathrm{C} / \mathrm{C}$ & $\mathrm{C}: 0.463, \mathrm{~T}: 0.537$ \\
\hline
\end{tabular}

ADIPOR2 was most significantly associated with waist circumference, IMT and FMD measurements in all individuals (Table 4). To be more specific, AA homozygotes and AG heterozygotes of the rs767870 had significantly higher IMTbulb and lower FMD values compared to GG homozygotes $(1.62 \pm 0.21 \mathrm{~mm}$ and $5.09 \pm 0.76 \%$ vs $1.26 \pm 0.07 \mathrm{~mm}$ and $7.62 \pm 0.74 \%$, $\mathrm{p}=0.025$ and $\mathrm{p}=0.002$, adjusted for age, sex, BMI, WHR and HOMA, respectively) (Table 4 and Fig.4A and $4 \mathrm{~B})$.

We then investigated the possibility that the association of rs767870 polymorphism with markers of endothelial dysfunction and atherosclerosis may be mediated through an effect on gene expression. In peripheral $\mathrm{CD}_{14}{ }^{+}$monocytes, carriers of the major A allele (homozygotes and heterozygotes) of rs767870 polymorphism had higher levels of ADIPOR2 protein expression compared to homozygotes of the minor allele $(69.17 \pm 4.80 \mathrm{MFI}$ and $92.03 \pm 14.41 \mathrm{MFI}$ vs $45.20 \pm$ 7.70 MFI, $\mathrm{p}=0.008$, after adjustment for age, sex, WHR and HOMA) (Table 4 and Fig. 4C).

\section{Discussion}

We have demonstrated for the first time that a sequence variant in the intron 5 of the ADIPOR 2, rs767870 among the eight studied, is associated with cardiovascular disease in our population of Greek individuals. Furthermore, genotypes from this variant are associated with higher IMT and lower FMD values in the same population, while they exhibit higher ADIPOR2 protein levels in circulating monocytes.

ADIPOR 1 and ADIPOR2 are considered promising genes for type 2 diabetes, the metabolic syndrome and its complications, such as cardiovascular disease [42]. The ADIPOR2 is located on chromosome 12p13.31 and comprises of eight exons. Various studies have associated genetic variants of the ADIPOR2 locus with insulin resistance and the traits of the metabolic syndrome [21-29], whilst several others have failed to confirm this [30-33]. In particular, ADIPOR2 variants have been strongly associated with type 2 diabetes in the Old Amish Order and in a Chinese population $[22,24]$.

Table 3 Associations between polymorphisms of ADIPOR2 and the risk of coronary artery disease

\begin{tabular}{|c|c|c|c|c|c|c|}
\hline SNPs & Major/minor allele & genotype & CAD (\%) & Non CAD (\%) & $p^{a}$ & $\begin{array}{c}\text { OR }(95 \% \mathrm{Cl}) \\
\mathbf{p}^{\mathbf{b}}\end{array}$ \\
\hline \multirow[t]{3}{*}{ rs767870 } & $A / G$ & AA & 70 & 64.2 & 0.017 & $0.479(0.465-5.120)$ \\
\hline & & $A G$ & 30.0 & 17.9 & & 0.999 \\
\hline & & GG & 0.0 & 17.9 & & \\
\hline \multirow[t]{3}{*}{ rs1044771 } & $\mathrm{C} / \mathrm{T}$ & CC & 22.5 & 10.7 & 0.510 & $0.557(0.317-8.454)$ \\
\hline & & $\mathrm{CT}$ & 50.0 & 67.9 & & 0.355 \\
\hline & & $\pi$ & 27.5 & 21.4 & & \\
\hline
\end{tabular}

Genotype distributions are shown as per cent (\%). ${ }^{a}$ p-value according to chi-square test, ${ }^{b}$ p-value according to binary logistic regression analysis, OR: Odds ratio, 95\% confidence interval $(\mathrm{Cl})$. 
Table 4 Anthropometric and metabolic characteristics of the study population divided according to the genotypes of rs767870 of the ADIPOR2

\begin{tabular}{|c|c|c|c|c|c|}
\hline rs767870 & $A / A$ & $A / G$ & G/G & $p$ & $p$ \\
\hline SEX (male/female) & $40 / 6$ & $15 / 2$ & $3 / 2$ & $0.25^{\mathrm{a}}$ & \\
\hline Age (years) & $58.50 \pm 1.29$ & $59.53 \pm 1.88$ & $54.80 \pm 2.48$ & 0.54 & \\
\hline Weight (Kg) & $81.73 \pm 1.43$ & $86.25 \pm 2.74$ & $75.10 \pm 3.58$ & 0.078 & \\
\hline Height (cm) & $1.70 \pm 0.01$ & $1.71 \pm 0.01$ & $1.63 \pm 0.01$ & 0.056 & \\
\hline BMI $\left(\mathrm{Kg} / \mathrm{m}^{2}\right)$ & $27.97 \pm 0.40$ & $29.46 \pm 0.82$ & $28.18 \pm 1.09$ & 0.198 & \\
\hline Waist circumference (cm) & $98.23 \pm 1.39$ & $103.37 \pm 2.55$ & $91.6 \pm 3.88$ & 0.040 & $0.067^{b}$ \\
\hline Hip circumference $(\mathrm{cm})$ & $101.52 \pm 1.01$ & $104.75 \pm 2.34$ & $100.20 \pm 2.99$ & 0.278 & \\
\hline WHR & $0.96 \pm 0.01$ & $0.99 \pm 0.01$ & $0.91 \pm 0.03$ & 0.128 & \\
\hline IMT (mm) & $1.01 \pm 0.05$ & $1.02 \pm 0.09$ & $0.65 \pm 0.09$ & $0.028^{c}$ & $0.053^{d}$ \\
\hline IMT bulb (mm) & $1.26 \pm 0.07$ & $1.62 \pm 0.21$ & $0.78 \pm 0.21$ & 0.019 & $0.025^{\mathrm{e}}$ \\
\hline FMD (\%) & $7.62 \pm 0.74$ & $5.09 \pm 0.76$ & $16.97 \pm 4.54$ & 0.0001 & $0.002^{\mathrm{e}}$ \\
\hline HOMA & $4.02 \pm 0.63$ & $4.42 \pm 0.47$ & $5.09 \pm 2.81$ & 0.887 & \\
\hline Matsuda & $2.87 \pm 0.24$ & $2.31 \pm 0.23$ & $3.12 \pm 0.72$ & 0.345 & \\
\hline Adiponectin $(\mu \mathrm{g} / \mathrm{ml})$ & $12.42 \pm 0.73$ & $15.82 \pm 2.86$ & $10.19 \pm 1.24$ & 0.168 & \\
\hline AdipoR2 mRNA (AU) & $1.02 \pm 0.12$ & $1.16 \pm 0.23$ & $0.83 \pm 0.10$ & 0.732 & \\
\hline AdipoR2 protein (MFI) & $69.17 \pm 4.80$ & $92.03 \pm 14.41$ & $45.20 \pm 7.70$ & 0.039 & $0.008^{f}$ \\
\hline
\end{tabular}

Data are means \pm SEM, ${ }^{a}$ chi square test, ${ }^{b}$ ANOVA for comparison among all three genotype groups adjusted for age and sex, ${ }^{\mathrm{C} A N O V A}$ for comparison among all three genotype groups after logarithmic transformation of values, ${ }^{\mathrm{A}} \mathrm{ANOVA}$ for comparison among all three genotype groups adjusted for age and BMI, after logarithmic transformation, ${ }^{\mathrm{e}} \mathrm{ANOVA}$ for comparison among all three genotype groups adjusted for age, sex, BMI, WHR and HOMA, ${ }^{\mathrm{f}} \mathrm{ANOVA}$ for comparison among all three genotype groups adjusted for age, sex, WHR and HOMA.

Other genetic variations of ADIPOR2 have been associated with decreased triglyceride levels in Mexicans with insulin resistance and in Germans with metabolic syndrome $[27,28]$.

We chose to study ADIPOR2 because the effects of $A D I P O R 2$ gene variants in cardiovascular disease have not yet been examined. It has been demonstrated that at least for $A D I P O R 1$, sequence variants in its 3'-region, are significant determinants of cardiovascular risk in type 2 diabetes [43]. Moreover in the same study, the authors have found that haplotypes of the above variants are also associated with lower ADIPOR1 mRNA levels in mononuclear cells and adipose tissue biopsies.

In our study, we have demonstrated that carriers of the major allele of the rs767870 polymorphism of the ADIPOR2 are associated with $78 \%$ higher ADIPOR2 protein expression in circulating monocytes, compared to homozygotes of the minor allele, independent of age, gender, obesity measures and insulin resistance. Furthermore, these same individuals compared to minor allele homozygotes, have $56 \%$ and $83 \%$ higher IMT values at both common carotids and carotid bulbs respectively, while at the same time they show 67\% lower FMD values, independent of age, gender, obesity measures and insulin resistance. It has been shown that the reduction of FMD increases the risk of coronary artery disease [44], whilst increments in the IMT measurements are associated with atherosclerosis progression [45]. In line with this, our findings could suggest that individuals carrying the A allele of the rs767870 polymorphism of $A D I P O R 2$ are prone to atherosclerotic events that could possibly be mediated via increased ADIPOR2 expression.

The mechanisms through which variations in the $A D I$ POR2 could influence atherosclerosis and cardiovascular disease are only hypothetical at the moment. The rs767870 polymorphism lies inside intron 5 of the $A D I$ POR2 locus and is not translated to amino acid. Nevertheless, such silent SNP could influence adiponectin receptor concentrations with unknown mechanisms. Our findings that genotypes of the rs767870 variant of the ADIPOR2 are associated with protein expression in circulating monocytes (the precursors of foam cells that populate atherosclerotic lesions), makes the hypothesis that $A D I P O R 2$ could affect atherosclerosis through its protein expression attractive.

Monocytes play a pivotal role in inflammation and atherosclerosis. These are the sites in which adiponectin exerts its anti-inflammatory and anti-atherogenic effects, mainly by inhibiting the secretion of inflammatory cytokines from monocyte-derived macrophages, by preventing monocyte adhesion to endothelial cells and by suppressing macrophage-to-foam cell transformation $[9,10]$. Whilst initially our findings that associate increased atherosclerosis with higher ADIPOR2 expression in monocytes seem paradoxical, one could consider a compensatory up-regulation mechanism of ADIPOR2 expression to exist in individuals with advanced atherosclerosis in order to counteract their adverse metabolic and cardiovascular outcomes. Furthermore, upregulation 

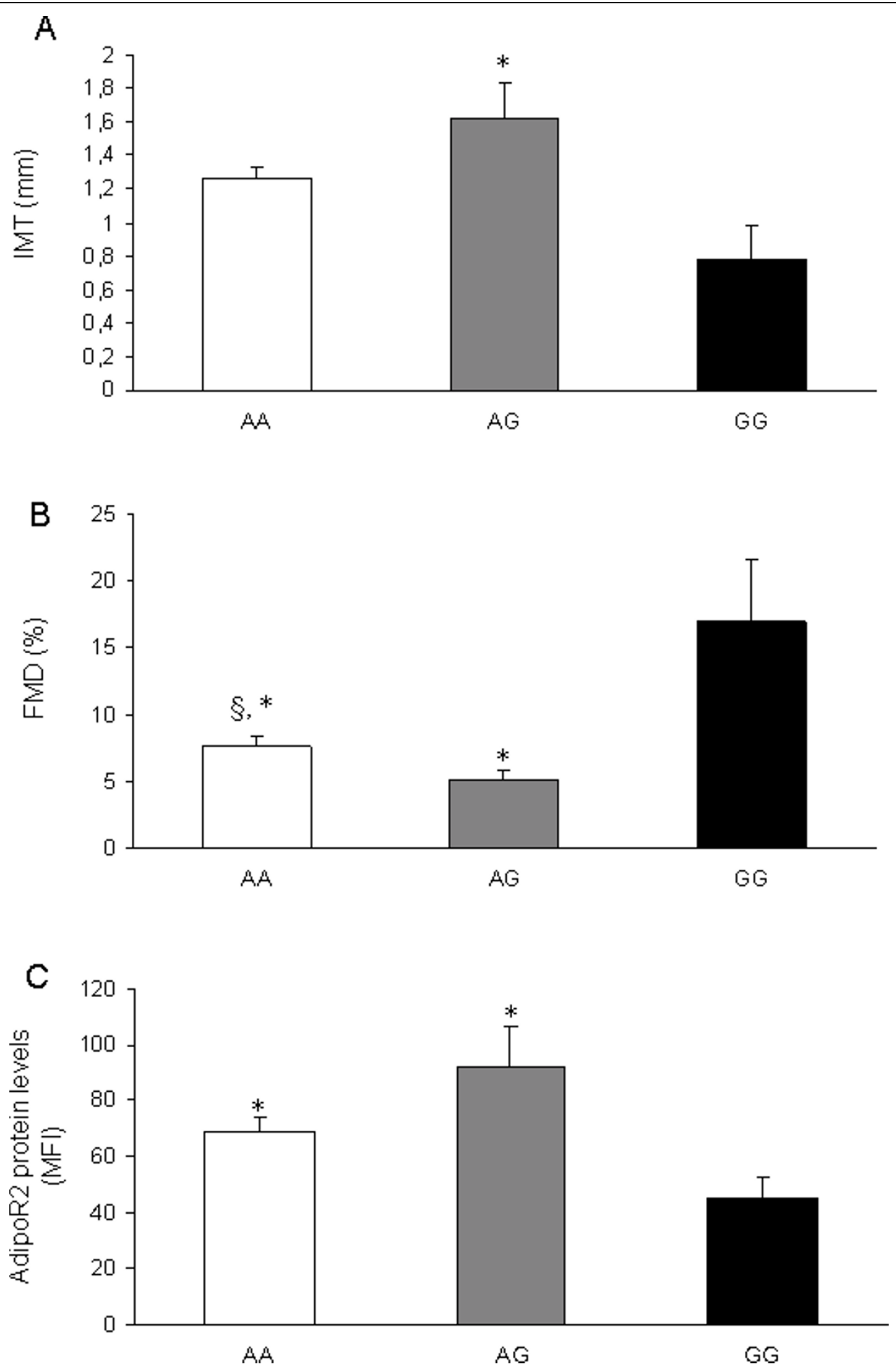

Figure 4 Genotype effects of the SNP 767870 of ADIPOR2 on the: (A) IMTbulb measurement, (B) FMD measurement and (C) ADIPOR2 protein levels from CD14+ monocytes. Data are means \pm SEM. Differences between genotype groups were analysed by ANOVA adjusted for age, sex, BMI, WHR and HOMA ( $A$ and $B, p=0.04$ and $p=0.002$ respectively) and ANOVA adjusted for age, sex, WHR and HOMA (C, $p=0.05$ ) ${ }^{*} p<0.05$ vs GG homozygotes $\$ p<0.05$ vs AG heterozygotes. 
of adiponectin receptors, which might reflect an increased need for adiponectin signalling has also been demonstrated in the adipose tissue of women with polycystic ovarian syndrome [19] and in the skeletal muscle of insulin resistant and type 2 diabetic subjects [16].

It is of particular interest that three different studies have identified the rs767870 variant of the ADIPOR2, as being associated either with triglyceride levels and fat accumulation or as a determinant of type 2 diabetes. More specifically, in a genetic association analysis in the French population, rs767870 was the only genetic marker associated with type 2 diabetes of the 12 ADIPOR2 SNPs studied [23]. The association remained significant in a meta-analysis study of three case-control studies. It was also the only one associated with liver fat content in the Finnish population [20]. Moreover, Richardson et al have demonstrated that homozygotes for the minor allele of rs767870 variant, were associated with lower triglyceride levels in insulin resistant Mexicans [28]. By contrast, this SNP was not associated with insulin resistance in another study in the German population [30].

However, our study findings should be interpreted bearing in mind some limitations. The number of our study subjects is generally regarded as small for genetic association studies. Nevertheless we found no major difference in the allelic frequencies of the rs767870 polymorphism in our Greek population, with the allelic frequencies in other European populations (HapMap$\mathrm{CEU}$ ). Nevertheless our findings must be confirmed on a larger sample and with other ethnicities.

\section{Conclusions}

Our data provides evidence for the first time that the rs767870 variant of the ADIPOR2 could be a determinant of endothelial disturbance and early atherosclerosis in the Greek population, independent of insulin resistance, possibly through the elevated ADIPOR2 protein expression in circulating monocytes.

\section{Acknowledgements}

This work (PENED\#03ED-597) was supported by E.U. European Social Fund (75\%) and the Greek Ministry of Development - General Secretariat of Research and Technology (GSRT) (25\%) and the private sector within the framework of the Operational Programme, "Competitiveness" (Measure 8.3) of the $3^{\text {rd }}$ Community Support Programme.

We would like to thank Ms V. Frangaki, R.N., for nursing help, Ms A. Koukourava for excellent technical assistance and Ms Ashley Putt Gkiokas for her help with language editing.

\section{Author details}

${ }^{1}$ Hellenic National Centre for the Research, Prevention and Treatment of Diabetes Mellitus and its Complications (HNDC), Athens, Greece. ${ }^{2}$ 2nd Department of Internal Medicine, Research Institute and Diabetes Centre, Medical School, University of Athens, "Attikon" University General Hospital, Athens, Greece. ${ }^{3}$ 2nd Department of Cardiology, Medical School, University of Athens, "Attikon" University General Hospital, Athens, Greece.

\section{Authors' contributions}

$\mathrm{IH}$ : carried out the molecular genetics studies and drafted the manuscript, PCT: carried out the plasma analysis of adiponectin, designed the study, made the statistical analysis and revised the manuscript, $\|$ : participated in ultrasound studies and manuscript editing, AK and PM: contributed to data acquisition and manuscript editing, EM: carried out the immunofluorescence studies, EB: contributed to manuscript editing, JL and GD: conceived and designed the study, TE, DTK and SAR: revised and gave the final approval of the manuscript. All authors read and approved the final manuscript.

\section{Competing interests}

The authors declare that they have no competing interests.

Received: 17 December 2009 Accepted: 23 February 2010

Published: 23 February 2010

\section{References}

1. Scherer PE, Williams S, Fogliano M, Baldini G, Lodish F: A novel serum protein similar to $\mathrm{C} 1 \mathrm{q}$, produced exclusively in adipocytes. J Biol Chem 1995, 270:26746-26749.

2. Hu E, Liang P, Spiegelman PM: AdipoQ is a novel adipose-specific gene dysregulated in obesity. J Biol Chem 1995, 27:110697-10703.

3. Maeda K, Okubo K, Shimomura I, Funahashi T, Matsuzawa Y, Matsubara K: CDNA cloning and expression of a novel adipose-specific collagen like factor, apM (Adipose Most Abundant Gene Trascriptant gene 1). Biochem Biophys/ Res Commun 1996, 221:286-289.

4. Nakano Y, Tobe T, Choi-Miura NH, Mazda T, Tomita M: Isolation and characterisation of GBP28, a novel gelatin binding protein purified from human plasma. J Biochem 1996, 120:803-812.

5. Weyer C, Funahashi T, Tanaka S, Hotta K, Matsuzawa Y, Pratley R, Tataranni A: Hypoadiponectinemia in Obesity and Type 2 Diabetes: Close Association with Insulin Resistance and Hyperinsulinemia. J Clin Endocrinol Metabol 2001, 86:1930-1935.

6. Arita Y, Kihara S, Ouchi N, Takahashi M, Maeda K, Miyagawa J, Hotta K, Shimomura I, Nakamura T, Miyaoka K, Kuriyama H, Nishida M, Yamashita S, Okubo K, Matsubara K, Muraguchi M, Ohmoto Y, Funahashi T, Matsuzawa Y: Paradoxical decrease of an adipose-specific protein, adiponectin, in obesity. Biochem Biophys Res Commun 1999, 257:79-83.

7. Kumada M, Kihara S, Sumitsuji S: Association of hypoadiponectinemia with coronary artery disease in men. Arterioscler Thromb Vasc Biol 2003, 23:85-89.

8. Hara K, Yamauchi T, Imai Y, Manabe I, Kadowaki T: Reduced adiponectin level is associated with severity of coronary artery disease. Int Heart J 2007, 48:149-153.

9. Yamauchi T, Kamon J, Minokoshi Y, Ito Y, Waki H, Uchida S, Yamashita S, Noda M, Kita S, Ueki K, Eto K, Akanuma Y, Froguel P, Foufelle F, Ferre $P$, Carling D, Kimura S, Nagai R, Kahn BB, Kadowaki T: Adiponectin stimulates glucose utilization and fatty-acid oxidation by activating AMP-activated protein kinase. Nat Med 2002, 8:1288-95.

10. Ouchi N, Kihara S, Arita Y, Maeda K, Kuriyama H, Okamoto Y, Hotta K, Nishida M, Takahashi M, Nakamura T, Yamashita S, Funahashi T, Matsuzawa Y: Novel modulator for endothelial adhesion molecules: Adipocyte-derived plasma protein, adiponectin. Circulation 1999, 100:2473-2476.

11. Ouchi N, Kihara S, Funahashi T: Adipocyte-derived plasma protein, adiponectin, suppresses lipid accumulation and class $A$ scavenger receptor expression in human monocyte derived macrophages. Circulation 2001, 103:1057-1063

12. Matsuda M, Shimomura I, Sata M, Arita $Y$, Nishida M, Maeda N, Kumada M, Okamoto Y, Nagaretani H, Nishizawa H, Kishida K, Komuro R, Ouchi N, Kihara S, Nagai R, Funahashi T, Matsuzawa Y: Role of adiponectin in preventing vascular stenosis. The missing link of adipovascular axis. $J$ Biol Chem 2002, 277:37487-37491.

13. Cattori Y, Suzuki M, Hattori S, Kasai K: Globular adiponectin upregulates nitric oxide production in vascular endothelial cells. Diabetologia 2003, 46:1543-1549.

14. Yokota T, Oritani K, Takahashi I, Ishikawa J, Matsuyama A, Ouchi N, Kihara S, Funahashi T, Tenner AJ, Tomiyama Y, Matsuzawa Y: Adiponectin, a new member of the family of soluble defense collagens, negatively regulates 
the growth of myelomonocytic progenitors and the functions of macrophages. Blood 2000, 96:1723-1732.

15. Yamauchi T, Kamon J, Ito Y, Tsuchida A, Yokomizo T, Kita S, Sugiyama T, Miyagishi M, Hara K, Tsunoda M, Murakami K, Ohteki T, Uchida S, Takekawa S, Waki H, Tsuno NH, Shibata Y, Terauchi Y, Froguel P, Tobe K, Koyasu S, Taira K, Kitamura T, Shimizu T, Nagai R, Kadowaki T: Cloning of adiponectin receptors that mediate antidiabetic metabolic effects. Nature 2003, 423:762-769.

16. Blüher M, Bullen JW, Lee JH, Kralisch S, Fasshauer M, Klotting N, Niebauer J, Schon MR, Williams CJ, Mantzoros CS: Circulating adiponectin and expression of adiponectin receptors in human skeletal muscle: associations with metabolic parameters and insulin resistance and regulation by physical training. I Clin Endocrinol Metabol 2006, 91:2310-2316.

17. Blüher M, Williams CJ, Kloting N, Hsi A, Ruschke K, Oberbach A, Fasshauer M, Berndt J, Schon MR, Wolk A, Stumvoll M, Mantzoros C: Gene expression of adiponectin receptors in human visceral and subcutaneous adipose tissue is related to insulin resistance and metabolic parameters and is altered in response to physical training. Diabetes Care 2007, 30:3110-3115.

18. Nannipieri M, Bonotti A, Anselmino M, Cecchetti F, Madec S, Mancini E, Baldi S, Santini F, Pinchera A, Rossi M, Ferrannini E: Pattern of expression of adiponectin receptors in human adipose tissue depots and its relation to the metabolic state. Int J Obes 2007, 31:1843-1848.

19. Tan BK, Chen J, Digby JE, Keay SD, Kennedy CR, Randeva HS: Up regulation of adiponectin receptor 1 and 2 mRNA and protein in adipose tissue and adipocytes in insulin resistant women with polycystic ovarian syndrome. Diabetologia 2006, 49:2723-2728.

20. Civitarese AE, Jenkinson C, Richardson T, Bajaj M, Cusi K, Kashyap S, Berria R, Belfort R, DeFronzo RA, Mandarino LJ, Ravussin E: Adiponectin receptors gene expression and insulin sensitivity in non diabetic Mexican Americans with or without a family history of type 2 diabetes. Diabetologia 2004, 47:816-820.

21. Weigert J, Neumeier M, Wanninger J, Wurm S, Kopp A, Schobber F, Filarsky M, Schaffler A, Zeitun N, Aslanidis C, Buechler C: Reduced response to adiponectin and lower abundance of adiponectin receptor proteins in type 2 diabetic monocytes. FEBS Letters 2008, 582:1777-1782.

22. Damcott CM, Ott SH, Pollin T, Reinhart LJ, Wang J, O'Connell JR, Mitchel BD, Shuldiner AR: Genetic variation in adiponectin receptor 1 and adiponectin receptor 2 is associated with type 2 diabetes in the old order Amish. Diabetes 2005, 54:2245-2250.

23. Vaxillaire $M$, Dechaume A, Vasseur-Delannoy V, Lahmidi S, Vatin $V$, Lepretre F, Boutin P, Hercberg S, Charpentier G, Dina C, Froguel P: Genetic analysis of ADIPOR1 and ADIPOR2 candidate polymorphisms for type 2 diabetes in the Caucasian population. Diabetes 2006, 55:856-861.

24. Liao YF, Chen LL, Zeng TS, Zheng J, Li HQ: Association of the +33371 A/G polymorphism in adiponectin receptor 2 gene with Type 2 diabetes in the Chinese population. J Endocrinol Invest 2007, 30:860-864.

25. Kotronen A, Yki-Jarvinen $H$, Aminoff $A$, Bergholm R, Pietilainen $\mathrm{KH}$ Westerbacka J, Talmud PJ, Humphries SE, Hamsten A, Isomaa B, Groop L, Orho-Melander M, Ehrenborg E, Fisher RM: Genetic variation in the ADIPOR2 gene is associated with liver fat content and its surrogate markers in three independent cohorts. Eur J Endocrinol 2009, 160:593-602.

26. Lopez-Bermejo A, Botas-Cervero P, Ortega-Delgado F, Delgado E, GarcíaGil MM, Funahashi T, Ricart W, Fernández-Real : Association of ADIPOR2 with liver function tests in type 2 diabetic subjects. Obesity 2008, 16:2308-2313

27. Broedl UC, Lehrke M, Fleischer-Brielmaier E, Tietz AB, Nagel JM, Göke B, Lohse P, Parhofer KG: Genetic variants of adiponectin receptor 2 are associated with increased adiponectin levels and decreased triglyceride/ VLDL levels in patients with metabolic syndrome. Cardiovasc Diabetol 2006, 5:11.

28. Richardson DK, Schneider J, Fourcaudot MJ, Rodriguez LM, Arya R, Dyer TD, Almasy L, Blangero J, Stern MP, DeFronzo RA, Duggirala R, Jenkinson CP: Association between variants in the genes for adiponectin and its receptors with insulin resistance syndrome (IRS)-related phenotypes in Mexican Americans. Diabetologia 2006, 49:2317-2328.

29. Kim JT, Kim Y, Cho YM, Koo BK, Lee EK, Sin HD, Jang C, Choi JW, Oh B, Park KS: Polymorphisms of ADIPOR1 and ADIPOR2 are associated with phenotypes of type 2 diabetes in Koreans. Clin End 2009, 70:66-74.
30. Stefan N, Machicao F, Staiger H, Machann J, Schick F, Tschritter O, Spieth C, Weigert C, Fritsche A, Stumvoll M, Häring HU: Polymorphisms in the gene encoding adiponectin receptor 1 are associated with insulin resistance and high liver fat. Diabetes 2005, 48:2282-2291.

31. Collins SC, Luan J, Thomson AJ, Daly A, Semple RK, O'Rahilly S, Wareham NJ, Barroso I: Adiponectin receptor genes: mutation screening in syndromes of insulin resistance and association studies for type 2 diabetes and metabolic traits in UK populations. Diabetologia 2007, 50:555-562.

32. Hara K, Horikoshi M, Kitazato $H$, Yamauchi Tnoda M, Ohashi J, Froguel P, Nagai R, Kadowaki T: Absence of an association between the polymorphisms in the genes encoding adiponectin receptors and type 2 diabetes. Diabetologia 2005, 48:1307-1314.

33. Qi L, Doria A, Giorgi E, Hu F: Variations in adiponectin receptor genes and susceptibility to type 2 diabetes in women: A tagging- SNP haplotype analysis. Diabetes 2007, 56:1586-1591.

34. Lekakis JP, Ikonomidis I, Tsibida M, Protogerou A, Papada A, Papapanagiotou A, Revela I, Papamichael CM, Kalofoutis AT, Kremastinos DT: Genetic variations of the endothelial nitric oxide synthase gene are related to increased levels of C-reactive protein and macrophage-colony stimulating-factor in patients with coronary artery disease. Thromb Haemost 2006, 96:520-8.

35. Ikonomidis I, Lekakis JP, Nikolaou M, Paraskevaidis I, Andreadou I, Kaplanoglou T, Katsimbri P, Skarantavos G, Soucacos PN, Kremastinos DT: Inhibition of interleukin-1 by anakinra improves vascular and left ventricular function in patients with rheumatoid arthritis. Circulation 2008, 117:2662-9.

36. Matthews DR, Hosker JP, Rudenski AS, Naylor BA, Treacher DF, Turner R: Homeostasis model assessment: insulin resistance and beta-cell function from fasting plasma glucose and insulin concentrations in man. Diabetologia 1985, 28:412-419.

37. Matsuda M, De Fronzo R: Insulin sensitivity indices obtained from oral glucose tolerance testing. Diabetes Care 1999, 22:1462-1470.

38. lannone MA, Taylor JD, Chen J, Li MS, Ye F, Weiner MP: Microsphere-based single nucleotide polymorphism genotyping. Methods Mol Biol 2003, 226:123-134.

39. Cai H, White PS, Torney D, Deshpande A, Wang Z, Marrone B, Nolan JP: Flow cytometry-based minisequencing: a new platform for highthroughput single-nucleotide polymorphism scoring. Genomics 2000, 66:135-143.

40. Tsiotra PC, Tsigos C, Yfanti E, Anastasiou E, Vikentiou M, Psarra K, Papasteriades C, Raptis SA: Visfatin, TNF-alpha IL-6 mRNA expression is increased in mononuclear cells from type 2 diabetic women. Horm Metab Res 2007, 39:758-763.

41. Rodriguez S, Gaunt RT, Day NMI: Hardy-Weinberg Equilibrium Testing of Biological Ascertainment for Mendelian Randomization Studies. Am J Epidemiol 2009, Advance Access published on January 6, DOI 10.1093/aje/ kwn359.

42. Yamauchi T, Kadowaki T: Physiological and pathophysiological roles of adiponectin and adiponectin receptors in the integrated regulation of metabolic and cardiovascular diseases. Int J Obes (Lond) 2008, 32:S13-S18.

43. Soccio T, Zhang YY, Bacci S, Miynarski W, Placha G, Raio T, Di Paola R, Marucci A, Johnstone MT, Klein S, Triscitta V, Doria A: Common Haplotypes at the Adiponectin Receptor 1 (ADIPOR1) Locus are associated with increased risk of Coronary Artery Disease in Type 2 Diabetes. Diabetes 2006, 55:2763-2770.

44. Djaberi R, Beishuizen ED, Pereira AM, Rabelink TJ, Smit JW, Tamsma JT, Huisman MV, Jeiken JW: Non-invasive cardiac imaging techniques and vascular tools for the assessment of cardiovascular disease in type 2 diabetes mellitus. Diabetologia 2008, 51:1581-1593.

45. de Groot E, van Leuven Sl, Duivenvorden R, Meuwese MC, Akdim F, Bots ML, Kastelein Jj: Measurement of carotid intima-media thickness to assess progression and regression of atherosclerosis. Nat Clin Pract Cardiovasc Med 2008, 5:280-288.

doi:10.1186/1475-2840-9-10

Cite this article as: Halvatsiotis et al:: Genetic variation in the adiponectin receptor 2 (ADIPOR2) gene is associated with coronary artery disease and increased ADIPOR2 expression in peripheral monocytes. Cardiovascular Diabetology 2010 9:10. 